\title{
The Effect of BAP and IBA on In Vitro Root Cultures of Acehnese Pomelo (Citrus maxima (Burm.) Merr.)
}

\author{
Ira Handayani1 , Laila Nazirah³ ${ }^{3}$ Rd. Selvy Handayani*2 \\ ${ }^{1}$ Master Student of Postgraduate of Agroecotechnology, Faculty of Agriculture, Universitas Malikussaleh, Aceh Utara, Indonesia \\ ${ }^{2}$ Postgraduate of Agroecotechnology, Faculty of Agriculture, Universitas Malikussaleh, Aceh Utara, Indonesia \\ ${ }^{3}$ Department of Agroecotecnology, Faculty of Agriculture, Universitas Malikussaleh. Aceh Utara, Indonesia \\ Reuleut Campus, Muara Batu, Aceh Utara 24355, Indonesia \\ *Corresponding author: selvy@unimal.ac.id
}

\section{ARTICLE HISTORY \\ Received : 13 February 2020 \\ Revised : 17 March 2020 \\ Accepted : 14 April 2020}

\section{KEYWORDS}

Roots;

Auxin;

Seeds;

Cytokinins;

Shoots;

\begin{abstract}
Acehnese pomelo is considered as a potential fruit to be developed for its economic and nutritional values. However, there is a main problem in developing this fruit. Pomelo sometimes is grown from seeds, but nowadays the fruits are often found to be having lesser seeds or even seedless. Besides, it is quite challenging to grow this local pomelo not only due to the scarce of the seeds, but it also cannot be conventionally germinated. Therefore, we need to develop this fruit through tissue culture. The purpose of this study was to investigate the effect of growth regulators on germination of pomelo seeds in vitro and its organ formation from in vitro root explants seed-originated of pomelo. The study was conducted at Plant Tissue Culture Laboratory, Faculty of Agriculture, Malikussaleh University. In October 2018 to April 2019. The research was divided into two separate experiments: 1) in vitro germination of pomelo seeds and 2) in vitro organ formation from root explants from of pomelo seeds. The first experiment using Complete Randomized Design (CRD) with 10 replications. The only factor observed was the use of BAP ( 0 and $2 \mathrm{mg} / \mathrm{l}$ ). The second experiment was the examination of plant organ formation from root explants of pomelo seeds. This experiment had 2 factors observed. The first factor was different concentrations of BAP $(0,1$, and $2 \mathrm{mg} / \mathrm{l})$. The second factor was the different concentration of IBA $(0,1.25$, and $2.5 \mathrm{mg} / \mathrm{l})$. The results indicated that the application of BAP influenced the germination of pomelo seeds. The application of $2 \mathrm{mg} / \mathrm{l}$ BAP attributed to slower growth of shoots and roots, but it demonstrated better number of shoots, roots and leaves compared to application of $0 \mathrm{mg} / \mathrm{l}$ BAP. Pamelo root explants can form adventitious shoots on media eventhough without growth regulator (BAP $0 \mathrm{mg} / \mathrm{l}+\mathrm{IBA} 0 \mathrm{mg} / \mathrm{l}$ ), but optimization still needs to be done in order to obtain the best concentration to initiate shoot formation.
\end{abstract}

This is an open access article under the CC-BY-SA license.

\section{INTRODUCTION}

Pomelo (Citrus maxima (Burm.) Merr.) is the largest citrus belonged to family Rutaceae originated from South and Southeast Asia. This exotic fruit is characterized by a large size, unique taste and scent and longer shelf-life, which has been developed for its economic and nutritional values (Susanto, 2004; Isaskar, et al., 2011).

Indonesia has many local pamelo germplasm with various shape, size, colour, taste, and seeds. Recently, there are 17 pomelo accessions that have been identified and announced as national superior varieties, including variety Giri Matang, one of local pomelo from Aceh (Pusat Perlindungan Varietas Tanaman, 2001). The previous research by Rahayu, et al. (2012) indicated that Aceh Province had more varieties of pamelo germplasm - besides Giri Matang. Characterization of Aceh pamelo has begun in Samalanga sub-district, Bireuen Regency, Aceh Province (Ismadi, et al., 2018).

Acehnese pomelo is a potential fruit to be developed for its unique characteristics. Nowadays, some varieties of pomelo are difficult to be found due to people begin to have no interest growing the fruit. This phenomenon can threaten the preservation of pomelo genetic resources from Aceh. It causes a serious problem in developing Acehnese pomelo, not only because of the availability of seeds, but also it is difficult to be germinated conventionally. Therefore, to overcome these problems, we should have an alternative technology to develop this fruit, by applying tissue culture. 
The availability of pomelo seeds is limited and it is difficult to be conventionally germinated. Therefore, we need to find an alternative to develop this plant besides using its seeds. Its plant parts that are often used as sources of explants in plant tissue culture techniques are the callus, leaves, shoots, and roots. In vitro plant tissue culture research on pomelo plants originating from leaf, root and epicotyl bud explants has been carried out by Tyas (2012), but it still needs a lot of optimization of plant growth regulator treatment, especially in root explants.

One of keys to the success of tissue culture propagation is the use of growth regulators (GRs). The types of GRs that are usually used for in vitro culture propagation are BAP (Benzyl Amino Purin) and IBA (Indole -3-butyric acid). Propagation in vitro by adding GRs to the media has been previously evaluated in various types of plants such as sweet orange (Almeida et al., 2002), durian (Handayani, et al.,2019), Mangosteen (Handayani, et al., 2013; Handayani, et al., 2018), Tawangmangu tangerine (Sofian, et al., 2018), and Pamelo (Tyas, et al., 2016) In Tawangmangu tangerines which were propagated in vitro, the application of $1 \mathrm{ppm} \mathrm{IBA}+2$ ppm BAP was found to be the best treatment (Sofian, et al., 2018). The best media to induce direct shoots on pomelo epicotyl and root explants were MS0 media (Tyas, 2002).

The purpose of this study was to determine the effect of growth regulators on germination of pomelo seeds in vitro and organ formation from root explants from seed origin in vitro. The success of this research will be very useful in the field for the conservation and preservation of scarce plants and the protection of Indonesian germplasm.

\section{MATERIALS AND METHODS}

\subsection{Place and Duration}

The research was conducted at Plant Tissue Culture Laboratory, from October 2018 to April 2019. The materials used were germinated roots derived from Acehnese pomelo seeds, alcohol 70\%, cloth bleaching and disinfectant Bayclin 20\%, detergent, distilled water, sucrose, agar, MS media (without GR), and growth regulators IBA and BAP. Tools used were Laminar Air Flow Cabinet, petri dishes, autoclave, oven, $\mathrm{pH}$ meter and planting media. The purpose of this study was to investigate the effect of growth regulators on germination of pomelo seeds in vitro and its organ formation from in vitro root explants seed-originated of pomelo.

\subsection{Research Methods}

This research divided into 2 experiments. The first experiment was seed germination in vitro and the second was the organ formation of root explants derived from pomelo seeds. This first experiment employed Randomized Complete Design (CRD) factor and 10 replications. The only factor observed was the application of BAP (0 and $2 \mathrm{mg} / \mathrm{l})$. The second experiment was root explant organ initiation. It had two factors observed: the application of BAP $0 \mathrm{mg} / \mathrm{l}$ (B0), $1 \mathrm{mg} / \mathrm{l}$ (B1) and $2 \mathrm{mg} / \mathrm{l}$ (B2). The second factor was the application of IBA 0 $\mathrm{mg} / \mathrm{l}$ (I0), $1.25 \mathrm{mg} / \mathrm{l}$ (I1) and $2.5 \mathrm{mg} / \mathrm{l}$ (I2). The seeds were obtained from white-fleshed pomelo in Bireuen, Aceh Province. The seeds were germinated in vitro in media for 4 weeks and then they have been subcultured in MS media. The roots grown from the germinated seeds then were cut $1 \mathrm{~cm}$ in size. These $1 \mathrm{~cm}$-roots then were planted horizontally in planting media, 4 explants in one media jar.

\subsection{Data Analysis}

Data collected were subjected to statistical analysis using F-Test at $5 \%$ probability level, where significant differences existed means were separated using Duncan's Multiple Range Test (DMRT). SAS v9.13 portable was the software used to analyse the data.

\section{RESULTS AND DISCUSSIONS}

\subsection{First experiments. Seed germination in vitro}

The results of first experiments showed that the application of BAP affected in vitro germination of pomelo seeds and also several parameters observed. The results were presented in Table 1.

Table 1. The effect of BAP application on pomelo seed germination at 8 weeks after application

\begin{tabular}{|c|c|c|c|c|c|}
\hline \multirow[b]{2}{*}{ BAP concentrations } & \multicolumn{5}{|c|}{ Observations ( 8 weeks after application) } \\
\hline & $\begin{array}{c}\text { Percentage of seed } \\
\text { growth (\%) }\end{array}$ & $\begin{array}{l}\text { Time of seed } \\
\text { growth (DAP) }\end{array}$ & $\begin{array}{l}\text { Time of root } \\
\text { growth (DAP) }\end{array}$ & Number of shoots & Number of leaves \\
\hline $0 \mathrm{mg} / \mathrm{l}$ & 84.9 a & $12.94 \mathrm{~b}$ & $5.11 \mathrm{~b}$ & $1.49 \mathrm{~b}$ & $2.20 \mathrm{a}$ \\
\hline $2 \mathrm{mg} / \mathrm{l}$ & $78.2 \mathrm{a}$ & $15.76 \mathrm{a}$ & $6.50 \mathrm{a}$ & $1.74 \mathrm{a}$ & $2.44 \mathrm{a}$ \\
\hline
\end{tabular}

Mean values followed by the same letters in the same columns did not differ significantly ( $\mathrm{P}=0.05)$ as determined by Duncan's Multiple Range Test $5 \%$

Results given Table 1 showed that the application 2 $\mathrm{mg} / \mathrm{l}$ of significantly increased the number of shoots grown from the seeds eventhough it took longer time for its shoots and roots to appear. However, the leaves did not respond well to the application of BAP. The application of cytokinin can induce cell division (mitosis division) in internal meristem. This division stimulates the development of transportation tissues on lateral shoots, so that the lateral shoots can attain the energy resulted from metabolism process (Taiz \& Zeiger, 2002). 
Handayani et al. (2018) found that the increase of BAP concentration has increased the percentage of shoot growth. They have evaluated that $2.5 \mathrm{mg} / \mathrm{l}$ of BAP was the best concentration in inducing the shoot growth of mangosteen in vitro. The results of pomelo seed germination shown in Figure 1.
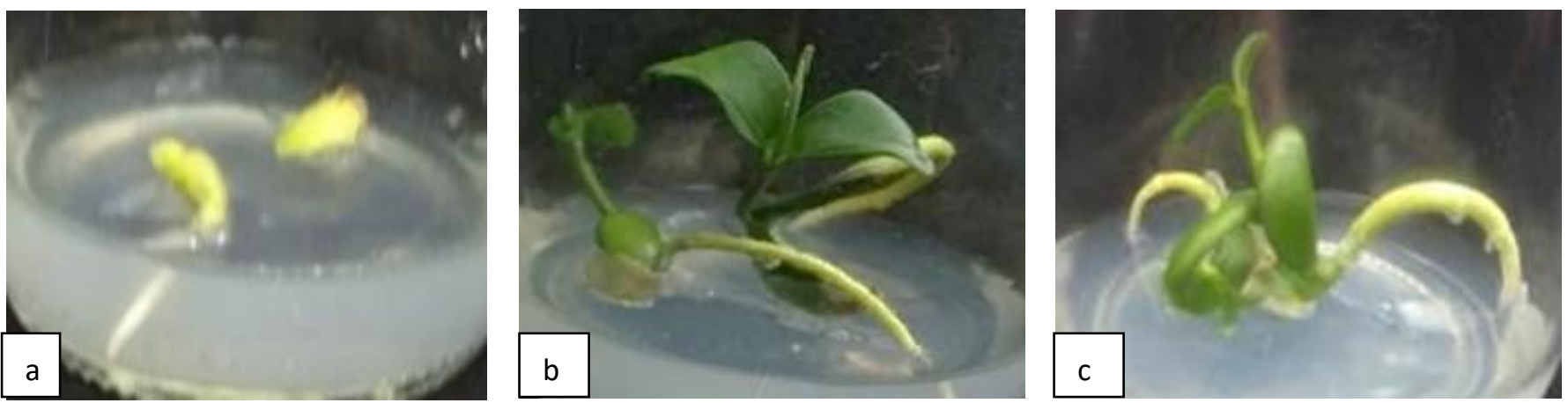

Figure 1. The appearance of seed germination in vitro in MS media without GR (MS0). Seed germinated at 7 weeks after application (a); Seed germinated at 4 weeks after application (b); Seed germinated at 5 weeks after application (c)

From the Figure 1, it has shown that these Acehnese pomelo seeds-which were known to be conventionally germinated- were germinatd well in tissue culture, even in media without growth regulators (MS0). The seeds were germinated at 7 weeks after application, and the roots often appeared earlier than the shoots (1a). The seeds then would be developed into shoots and leaves perfectly a few weeks later.

\begin{abstract}
3.2 Second experiment. Root explant organ initiation

Organogenesis development in root explants demonstrated dissatisfying results. From all explants applied with BAP and IBA, only few treatments responded. The data analysis was not applied due to fewer number of explants appeared. The effect of BAP and IBA applications on time of shoot growth and number of shoots was described in Table 2.
\end{abstract}

Table 2. The effect of BAP and IBA applications on the time of shoot growth and number of shoots of pomelo root explant

\begin{tabular}{|c|c|c|c|}
\hline & ments & Time of shoot growth (weeks after application) & Number of shoots \\
\hline BAP $0.00 \mathrm{mg} / \mathrm{l}$ & IBA $0.00 \mathrm{mg} / \mathrm{l}$ & 38 & 1 \\
\hline BAP $0.00 \mathrm{mg} / \mathrm{l}$ & IBA $1.25 \mathrm{mg} / \mathrm{l}$ & 8 & 1 \\
\hline BAP $0.00 \mathrm{mg} / \mathrm{l}$ & IBA $2.50 \mathrm{mg} / \mathrm{l}$ & Not appeared & Not appeared \\
\hline BAP $1.00 \mathrm{mg} / \mathrm{l}$ & IBA $0.00 \mathrm{mg} / \mathrm{l}$ & 50 & 1 \\
\hline BAP $1.00 \mathrm{mg} / \mathrm{l}$ & IBA $1.25 \mathrm{mg} / \mathrm{l}$ & Not appeared & Not appeared \\
\hline BAP $1.00 \mathrm{mg} / \mathrm{l}$ & IBA $2.50 \mathrm{mg} / \mathrm{l}$ & Not appeared & Not appeared \\
\hline BAP $2.00 \mathrm{mg} / \mathrm{l}$ & IBA $0.00 \mathrm{mg} / \mathrm{l}$ & Not appeared & Not appeared \\
\hline BAP $2.00 \mathrm{mg} / \mathrm{l}$ & IBA $2.50 \mathrm{mg} / \mathrm{l}$ & Not appeared & Not appeared \\
\hline BAP $2.00 \mathrm{mg} / \mathrm{l}$ & IBA $2.50 \mathrm{mg} / \mathrm{l}$ & Not appeared & Not appeared \\
\hline
\end{tabular}

The results given in Table 2 showed that there were only 3 treatments had better response to the growth of root explants. The application of growth regulators 1 $\mathrm{mg} / \mathrm{l}$ of BAP and $1.25 \mathrm{mg} / \mathrm{l}$ IBA have affected the root explants, where they can have shoots in shorter time.
However, the application of growth regulators did not respond well on the number of shoots. The explants only produced one shoot during research. The application of these regulators also affected the shoot length. The results were illustrated in Table 3.

Table 3. Effect of BAP and IBA on shoot length of pomelo root explant

\begin{tabular}{llcr}
\hline & & & \\
& Treatments & Shoot length (cm) \\
\cline { 3 - 4 } & & 6 weeks after application & 7 weeks after application \\
BAP $0.00 \mathrm{mg} / \mathrm{L}$ & IBA $0.00 \mathrm{mg} / \mathrm{L}$ & 0.5 & 1.0 \\
BAP $0.00 \mathrm{mg} / \mathrm{L}$ & IBA $1.25 \mathrm{mg} / \mathrm{L}$ & 0.7 & 0.8 \\
BAP $0.00 \mathrm{mg} / \mathrm{L}$ & IBA $2.50 \mathrm{mg} / \mathrm{L}$ & Not appeared & Not appeared \\
BAP $1.00 \mathrm{mg} / \mathrm{L}$ & IBA $0.00 \mathrm{mg} / \mathrm{L}$ & 0.4 & 0.5 \\
\hline
\end{tabular}




\begin{tabular}{lllr} 
BAP $1.00 \mathrm{mg} / \mathrm{L}$ & IBA $1.25 \mathrm{mg} / \mathrm{L}$ & Not appeared & Not appeared \\
BAP $1.00 \mathrm{mg} / \mathrm{L}$ & IBA $2.50 \mathrm{mg} / \mathrm{L}$ & Not appeared & Not appeared \\
BAP $2.00 \mathrm{mg} / \mathrm{L}$ & IBA $2.50 \mathrm{mg} / \mathrm{L}$ & Not appeared & Not appeared \\
BAP $2.00 \mathrm{mg} / \mathrm{L}$ & IBA $2.50 \mathrm{mg} / \mathrm{L}$ & Not appeared & Not appeared \\
BAP $2.00 \mathrm{mg} / \mathrm{L}$ & IBA $2.50 \mathrm{mg} / \mathrm{L}$ & Not appeared & Not appeared \\
\hline
\end{tabular}

The results in Table 3 illustrated that the application of BAP and IBA was insignificant on shoot length. Surprisingly, the shoots appeared from root explants planted on untreated MS media seemed to have longer size compared to treated MS media. The results were presented in Figure 2.
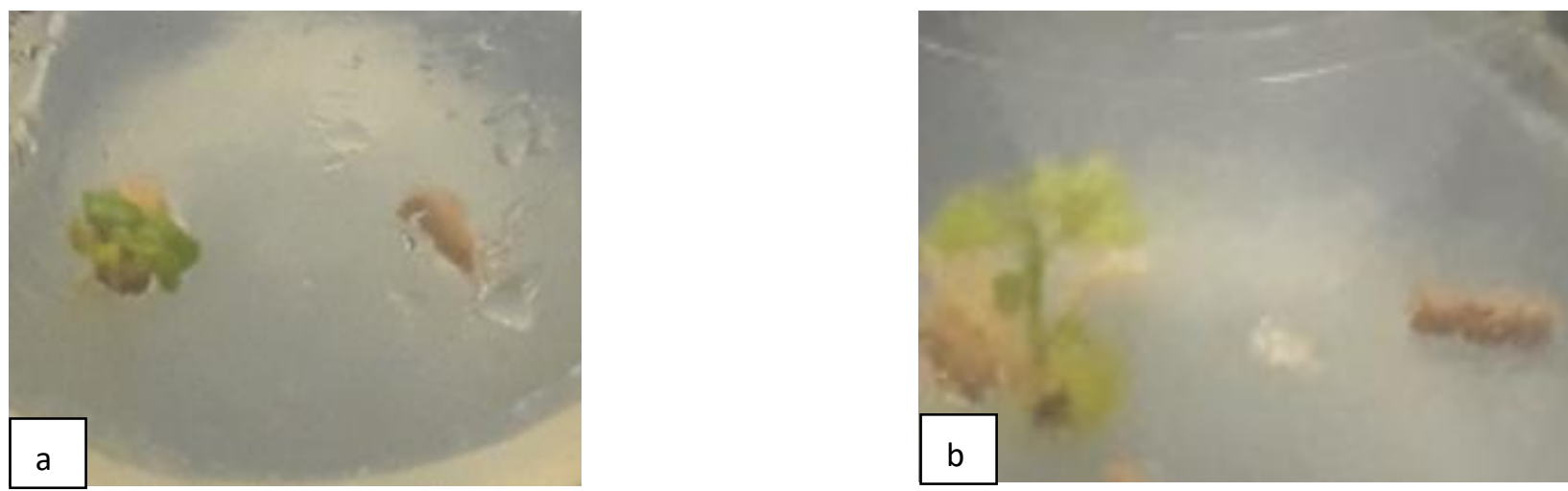

Figure 2. The appearance of leaves grown from root explants in vitro. BAP $0.00 \mathrm{mg} / \mathrm{l}+\mathrm{IBA} 0.00 \mathrm{mg} / \mathrm{l}(\mathrm{a})$; BAP $0.00 \mathrm{mg} / \mathrm{l}+\mathrm{IBA} 1.25$ $\mathrm{mg} / \mathrm{l}(\mathrm{b})$

From Figure 2 we can see that root explants derived from seeds can produce shoots and leaves in media without growth regulators (1a). Plant Growth Regulators (PGRs) or phytohormones are non-nutrient organic compounds used to regulate the growth of cultivated plants, weeds and in vitro grown plants and plant cells. PGRs are needed for certain processes, at certain times in plant growth and development processes (Hendaryono \& Wijayanti, 2004). In general, these hormones are needed to regulate the initiation and development of shoots and roots in explants in culture media, as well as stimulate cell division and enlargement (Beyl, 2004).

Both auxin and cytokinin have been known for a long time to act either synergistically or antagonistically to control several significant development processes. They are often applied to planting media to induce the growth and organogenesis in tissue and organ culture. The most important role of auxins and cytokines is to reprogram the determined merismatic cells. This reprogramming will cause cell redifferentiation in the new plant development processes (Gray \& Trigiano, 2005).

Explants have different responses in absorbing nutrients. Growth of root explants resulting from seed germination in vitro depends on the concentrations of growth regulators applied. In this study, root explants planted in several treatments could produce shoots and leaves on media without growth regulators applied (Figure 1). Root explants can form adventitious shoots. It happened due to roots are where cytokinins often produced (Taiz \& Zeiger, 2002) which play important role in inducing shoot growth (Srivastava, 2002). The existence of high endogenous cytokinin in the roots might contribute to the formation of adventitious shoot in root explants in untreated MS media.

In this study, not all PGR treatments have stimulated explants to produce shoots or other organs. The application of proper concentration of PGR to initiate the growth of shoots in pomelo root explants still needs further optimization in order to determine the best concentration for this plant. The balance between cytokinins and auxins in plant is very influential for organ development. More auxin will induce callus formation, while more cytokinins will induce shoot (Fereol et al., 2002). The use of GRs in small amounts can help the growth of explants. On the contrary, the use of GRs in high concentration can be toxic to plants, inhibit the plant development and also can kill plants (Mandang, 2013).

\section{CONCLUSION}

The application of BAP influenced seed germination in vitro. The use of $2 \mathrm{mg} / \mathrm{l}$ concentration of BAP induced slower development of pomelo shoots and roots. However, it produced better number of shoots and leaves compared to untreated pomelo seeds $(0 \mathrm{mg} / \mathrm{l})$. Pomelo root explants can form adventitious shoots in media without PGRs application (BAP $0 \mathrm{mg} / \mathrm{L}+\mathrm{IBA} 0 \mathrm{mg} / \mathrm{L}$ ), but the optimization is still needed to obtain the best concentration to initiate shoot formation. 


\section{REFERENCES}

Almeida, R. P., Nascimento, F. E., Chau, J., Prado, S. S., Tsai, C. W., Lopes, S. A., \& Lopes, J. R. (2008). Genetic structure and biology of Xylella fastidiosa strains causing disease in citrus and coffee in Brazil. Appl. Environ. Microbiol., 74(12), 3690-3701.

Beyl, C. (2004). Getting Started with Tissue Culture. Plant Development and Biotechnology, 19-37.

Gray, D. J., \& Trigiano, R. N. (2004). Getting started with tissue culture: media preparation, sterile technique, and laboratory equipment. In Plant Development and Biotechnology (pp. 15-37). CRC Press.

Handayani, R. S., Yunus, I., Sayuti, M., \& Irawan, E. (2019). In-vitro Callus Induction of Durian (Durio zibethinus Murr.) Leaves Using Kinetin and 2, 4-D (Dichlorophenoxyacetic acid). Journal of Tropical Horticulture, 2(2), 59-64.

Handayani, R. S., Maisura, M., \& Rizki, A. (2018). Pengaruh Letak Posisi Eksplan dan Sitokinin Pada Perkecambahan Biji Manggis (Garcinia mangostana L.) Lokal Aceh Secara in-Vitro. Jurnal Agrium Unimal, 14(2), 1-8.

Handayani, R. S., Poerwanto, R., Purwito, A., \& Ermayanti, T. M. (2013). Pengaruh Batang Bawah dan Jenis Tunas pada Mikrografting Manggis (Garcinia mangostana) secara In Vitro. Jurnal Agronomi Indonesia (Indonesian Journal of Agronomy), 41(1).

Hendaryono, D. P. S., \&. Wijayani, A. (2004). Teknik Kultur Jaringan. Kanisius. Yogyakarta.

Isaskar, R., \& Syafrial, S. (2015). Efisiensi Pemasaran Jeruk Pamelo Dalam Wilayah Magetan (Citrus grandis L. Osbek). Habitat, 22(1), 60-70.

Ismadi,, Putri, I. Y., \& Hafifah, H. (2018). Characterization of Pamelo Leaves (Citrus maxima (Burm) Merr) Aceh, Indonesia. Journal of Tropical Horticulture, 1(1), 20-23.
Mandang, J. S. (2013). Media Kultur Jaringan Tanaman. Manado: Bayumedia Publishing Anggota IKAPI.

Rahayu, A. R. I. F. A. H. (2012). Karakterisasi dan Evaluasi Aksesi Pamelo (Citrus maxima (Burm) Merr.) Berbiji dan Tidak Berbiji Asli Indonesia. Disertasi Sekolah Pascasarjana, Institut Pertanian Bogor, Bogor.

Rahayu, A., Susanto, S., Purwanto, B. S., Dewi, I.S. (2012). Karakter morfologi dan kimia kultivar pamelo (Citrus maxima (Burm.) Merr.) berbiji dan tanpa biji. Jurnal Agronomi Indonesia (Indonesian Journal of Agronomy), 40(1), 48-55

Sofian, A. A., Prihastanti, E., \& Suedy, S. W. A. (2018). Effect of IBA and BAP on Shoot Growth of Tawangmangu Tangerine (Citrus reticulate) by In-Vitro. Biosaintifika: Journal of Biology \& Biology Education, 10(2), 379-387.

Srivastava, L. M. (2002). Plant Growth and Development Hormon and Envirotment. Accademic Press, London.772 p.

Féréol, L., Chovelon, V., Causse, S., Michaux-Ferriere, N., \& Kahane, R. (2002). Evidence of a somatic embryogenesis process for plant regeneration in garlic (Allium sativum L.). Plant Cell Reports, 21(3), 197-203.

Susanto, S. (2004). Perubahan kualitas buah jeruk besar (Citrus grandis (L.) Osbeck) yang disimpan dan dibiarkan di pohon. Hayati, 11(1), 25.

Taiz, L. \& Zeiger, E. (2002) Plant Physiology, California, The Benjamin/ Cummings Pub. Co. Inc., 559 p.

Tyas, K. N. (2012). Organogenesis dan Konservasi in vitro pamelo (Citrus maxima (Burm.) Merr). Disertasi Institut Pertanian Bogor.

Tyas, K. N., Susanto, S., Dewi, I. S., \& Khumaida, N. (2016). Organogenesis tunas secara langsung pada pamelo (Citrus maxima (Burm.) Merr.). Buletin Kebun Raya, 19(1), 01-10. 